



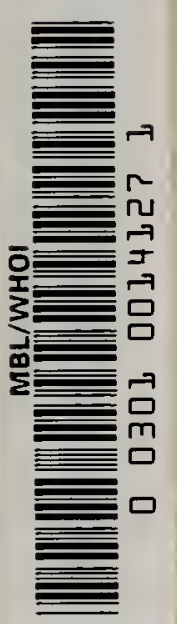


8319 


\section{MUSHROOMS OF AMERICA, EDIBLE AND POISONOUS.}

EDITED BY JULIUS A. PALMER, JR.

PUBLISHED BY L. PRANG \& CO., BOSTON.

(COPYRIGHT, 1888, BY L. PRANG \& CO.)

\section{GENERAL DIRECTIONS.}

These charts are prepared for popular use, rather than for students of botanical science; all technical terms are, therefore, as far as possible, avoided.

The names "mushroom" and "toadstool" are indefinite, are both applied with equal reason to any fleshy fungus, and are bere used as synonymes, like the corresponding terms "plant" and "vegetable," or. "shrub" and "bush," in common conversation.

No general test can be given by which a poisonous mushroom may be distinguished from an edible mushroom. But each species of fungus has certain marks of identity, either in appearance, quality, or condition of growth, which are its own, and never radically varied; none can contain a venomous element at one time, and yet be harmless under other conditions. Like other food, animal or vegetable, however, musbrocms may, by decay or conditions of growth, be unfit for table use; yet in this state no fatality would attend such use.

Therefore the identification of species is a safe guide, and is the only means of knowing what mushrooms should be eaten, and what varieties of fungus should be rejected. Having once learned to distinguish any species of mushrooms as esculent, perfect security may be felt in the use of that species wherever and whenever found; but any specimen varying from the type in the slightest degree should be rejected by an amateur.

There are about one thousand varieties of mushrooms (exclusive of small or microscopic fungi) native to the United States; many will therefore be found which are not represented on either of these plates. Those here depicted are of three classes, namely, the Lycoperdaceæ, or Puff-ball fungi; the Agaricini, or Gill-bearing fungi; and the Boleti, which last is one division of the Polyporei, or Pore-bearing fungi. 

The following definitions are here given, and will be found necessary:-

PILEUS. The expanded disk or cap of the mushroom or toadstool.

GILLS. The thin plates set on their edges under the pilcus, running to a common centre at the stem.

TUBES. The spongy collection of pores which take the place of gills under the pileus of a Boletus.

VEIL. A web or membrane which extends from the margin of the pileus to the stem when the mushroom is young, and thus encloses the gills.

RING. A part of the veil adherent to the stem, and forming a collar around it.

VOL $\boldsymbol{V A}$. The sheath or wrapper enclosing the young mushroom, when below or just above the ground; the rcmains of which are found in the ring, the vcil, at the base of the stem, and in the warty or scurfy top of some varieties of mushrooms.

SPORES. The reproductive bodies, analogous to seeds in somc other plants, found under the caps of the Agaricini and Bolcti, and appearing like fine dust when the cap is left for a time lying under-side downward.

There are as many diffcrent flavors and tastes among esculent fungi as are found in any other varieties of diet, and the very general ignorance of this fact is a sufficient reason for the issue of this work. Many pcrsons claim to know a mushroom from a toadstool. This means that there is one variety out of a thousand of which they eat with safety, and it means nothing more. A person might as well select one fish from the sea, and avoid all other members of the finny tribe on the ground that there are poisonous fishes. It is strange that this general ignorance is most apparent in the case of the English-speaking people. The fungus eatcrs form a little cliquc in England, but the majority of her people know nothing of this gratuitous offering from Nature's storehouse. No country is richer in mushroom food than America. Were the poorer classes of Russia, Germany, Italy, or France to see our forests during the autumn rains, they would feast on the rich food there going to waste. For this harvest is spontaneous; it requires no seed-time, and asks for no peasan's toil. At the same time, the economic value of mushroom diet ranks second to meat alone. With bread, and mushrooms properly gathered and prcparcd, a person may neglect the butcher during the summer months. This is self-crident to the unscientific mind by the simple facts that mushrooms make the same use of the air we brenthe as is madc by animals, that cooked they resemble no form of vegetable food, and that in decay their odor in some cases cannot be distinguishcd from that of putrid meat. To this feast, abundantly provided by Nature for the poorest as well as the most epicurean, we invitc the American people. 

In gathering mushrooms for foor, cut the stem off about an ineh below the cap, and place them in the basket or dish, gills upward. Never twist or pull them, as the gills become thereby full of dirt, whieh is not easily removed. By plaeing them gills downward, they will shed their spores largely and thus lose flavor.

The stem in eutting will often exhibit fine holes; this indicates that maggots have entered the mushroom. If the substance of the pileus continues firm and hard, the mushroom may be cooked and eaten by those not over-nice; but if perforated and soft, the consequent decomposition might induee nausea, und even serions sickness.

Mushrooms maly be noxious as food in three ways :-

(1.) They may disagree with the system, by their toughness, indigestibility, or use in a state of deeay.

(2.) They may be slimy, aerid, or otherwise nauseous.

(3.) They may eontain a subtle poison without taste, smell, or other indieation of its presenee.

Most noxious fungi appertain to the first or second elass abore given, and taste or eommonsense would readily reject them, unless they were eooked with other food or exeessively spiced. For this reason plain cooking is advised, and further, no amateur should venture to mingle with good varieties others to him unknown.

Of the third elass, there is one family, many of whose members eontain a violent and deadly poison. This is knowu as the Amanita family; and although out of fourteen varieties, four are known to be edible, yet it is here advised to avoid all fungi as food whieh have these its distinguishiug marks :- -

(1.) A scurfy or warty top, the protuberances of which rub easily off, leaving the skin intact. In a number of speeimens many will be found entirely smooth, while near them are others of the same variety where more or less of the speeks remain.

(2.) A ring; generally large and reflexed or fulling downward.

(3.) A volva; more or less enclosing the young plant, and remaining at the base of the older speeimen, so that when the mushroom is pulled up a socket is left in the ground.

These three marks should all exist in the typieal plant of this family, and the experienced eye will see signs of their presence, even where they are wanting. But the volva rarely or never deeays during the life of the speeimen, and to rejeet everything with this mark is reeommended to all amateurs.

So far as known, there are no eases of death by the use of mushrooms except from this one family. In all well-defined eases of fatal poisoning, the eause is just as well defined, namely, the use of the mushroom represented by Plates IX. and X. in this sheet. Therefore, when one has become perfeetly acquainted with this family, and learned to always reject them, he has.very little to fear in the ehoice of mushrooms for the table. The poisonous varieties of the Amanita family are extremely eommon. 

The antidote for this poison is found in the skilful use of the alkaloids from the family of the Solanacee or Nightshades, especially in subcutaneous injections of Atropine. But to the public generally, in cases of poisoning, no other advice can be given than to call a physician without delay.

Plate VI. represents several members of the Russula family. Haring once learned to identify it without danger of error, this family is quite safc for use as food; for all the non-esculent Russulas are hot or nauscous to the taste, while the edible ones are very nutty and pleasant. The student should, therefore, taste each specimen when preparing them for cooking.

Some authorities consider all Bolcti fit for table use, but there are those which are too bitter for food, and one such as the specimcn numbered 1, Plate XI., would spoil a whole stew. The tubes of this Boletus (felleus) are light rose, although they appear to be white when fresh and young. A good rule for amateurs is to avoid all the lurid Boleti; by this is meant all those that have the slightest shade of rcd to the tubes, although I have oftcn eaten of such. The mild-colored members of this family, having white, yellow, or greenish tubes, if plcasant to the taste, may be eonsidcred safe eating.

Plate VIII. represents some of the esculent puff-balls. There are some warty fungi growing on wood, which, in early growth, resemble puff-balls, whose qualities are not yet known. But all those varieties of clear white fungi, which appear in little balls on the open ground after rains, may be eaten with perfect safcty, if fresh, whitc inside, and hard; if soft and yellowish, or black in the pulp, they should be avoided, as they are approaching decay.

The most important advice to the student is to learn to recognize the Amanita family, and to avoid them all; next, to define and reeognize any mushrocm he is using for food, so that he could pick a single specimen of the same out of a basketful of assorted fungi; and finally, never to pick mushrooms at random for food, unless he has tested by actual use each and all of the varieties so nsed. There is a large family of mushrooms resembling the Russulas, which exude a milky juice if broken or cut. The amateur will do well to avoid all such, although they are esculent where the milk is mild to the taste. Additional plates, displaying other varieties of esculent mushrooms, may possibly be issued in the future.

JULIUS A. PALMER, JR. 



\section{AGARICUS CAMPESTRIS ET ARVENSIS, OR MUSHROOM PROPER.}

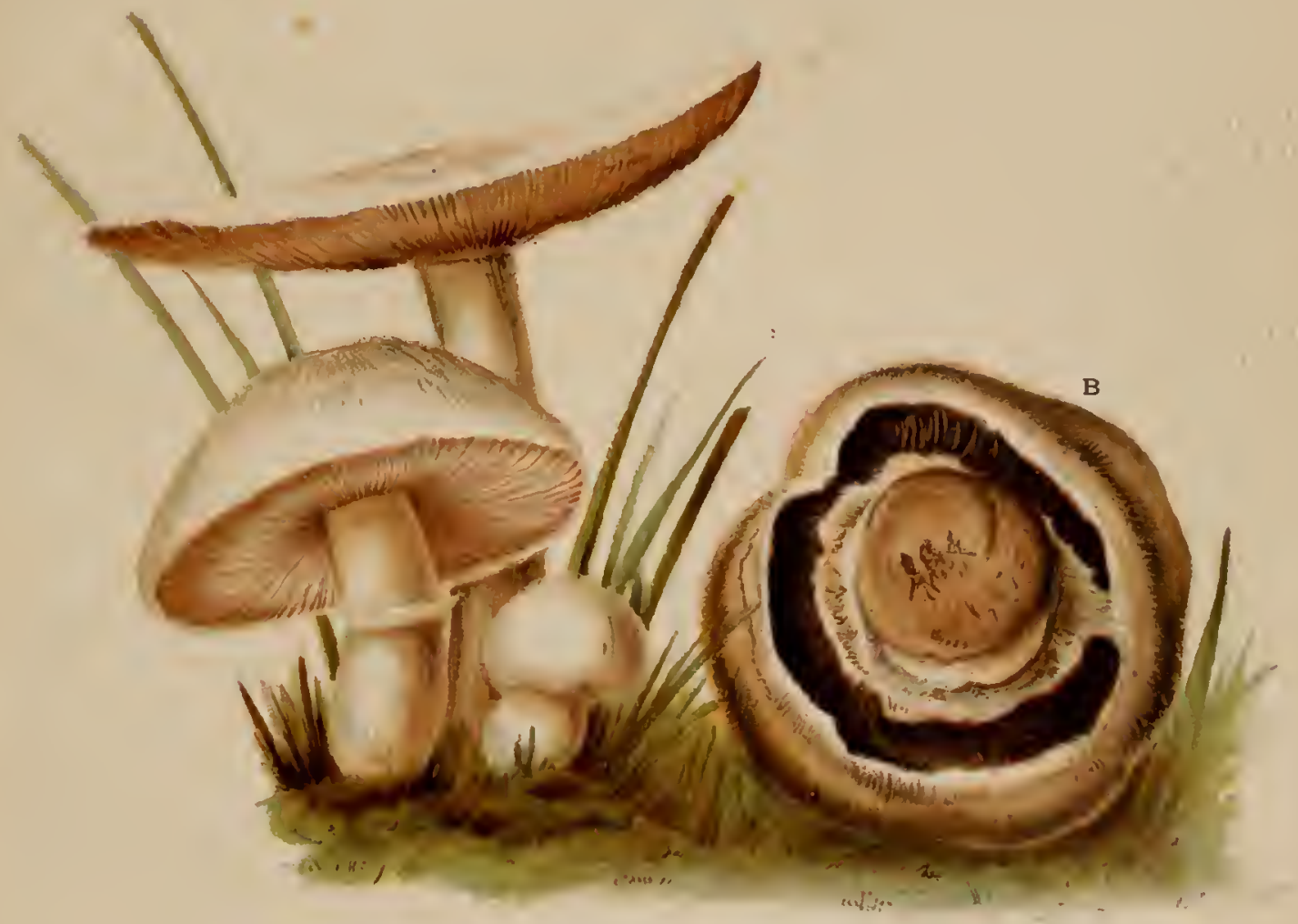

DESCRIPTION. PIleus. Dry, silky or downy from the first; globular, margin united to the sten by the veil, then expanded, bell-shaped, at last even flat. Color variable, from white to dark brown. Cuticle easily separable in pasture variety.

GiLls. At first pink, theu purple, finally almost black, never white; of different lengths.

Stem. Nearly solid, even in size, easily removed from the socket.

Vozva. None; but veil present, at first enclosing gills, tlien making a ring, fimally absent.

SPORES. Purple or purplish brown. TASTE AND SMELL fragrant and agreeable.

Grows in open pastures, lanes or roadsides; never in forests

(B.) Similar to above, but coarser, more brittle and of stronger flavor; turus rust of iron color when bruised; grows on banks, street-sweepings and in hot-houses.

TO COOK. Stew in milk or cream; prepare to serve with meat as described under Plate II., or broil as directed under Plate III.

TO ROAST IN THE OVEN. Cut the larger specimens iuto fine pieces, and place thein in a small dish, with salt, pepper and butter to taste; put in about two tablespoonfuls of water, then fill the dish with the lati-open specinens and the buttons; cover tightly and place in the oven, which must not be overheated, for about twenty minutes. The juice of the larger muslirooms will keep them moist, and, if fresh, yield further a most abundaut gravy.

N. B. In gathering the pasture rariety, cut them just below the cap (don't pull them); they cun then be cooker without washing or peeling. The cultivated mushrooms are often so dirty as to require both washing and peeling. 



\section{COPRINUS COMATUS, OR SHAGGY-MANED MUSHROOM.}

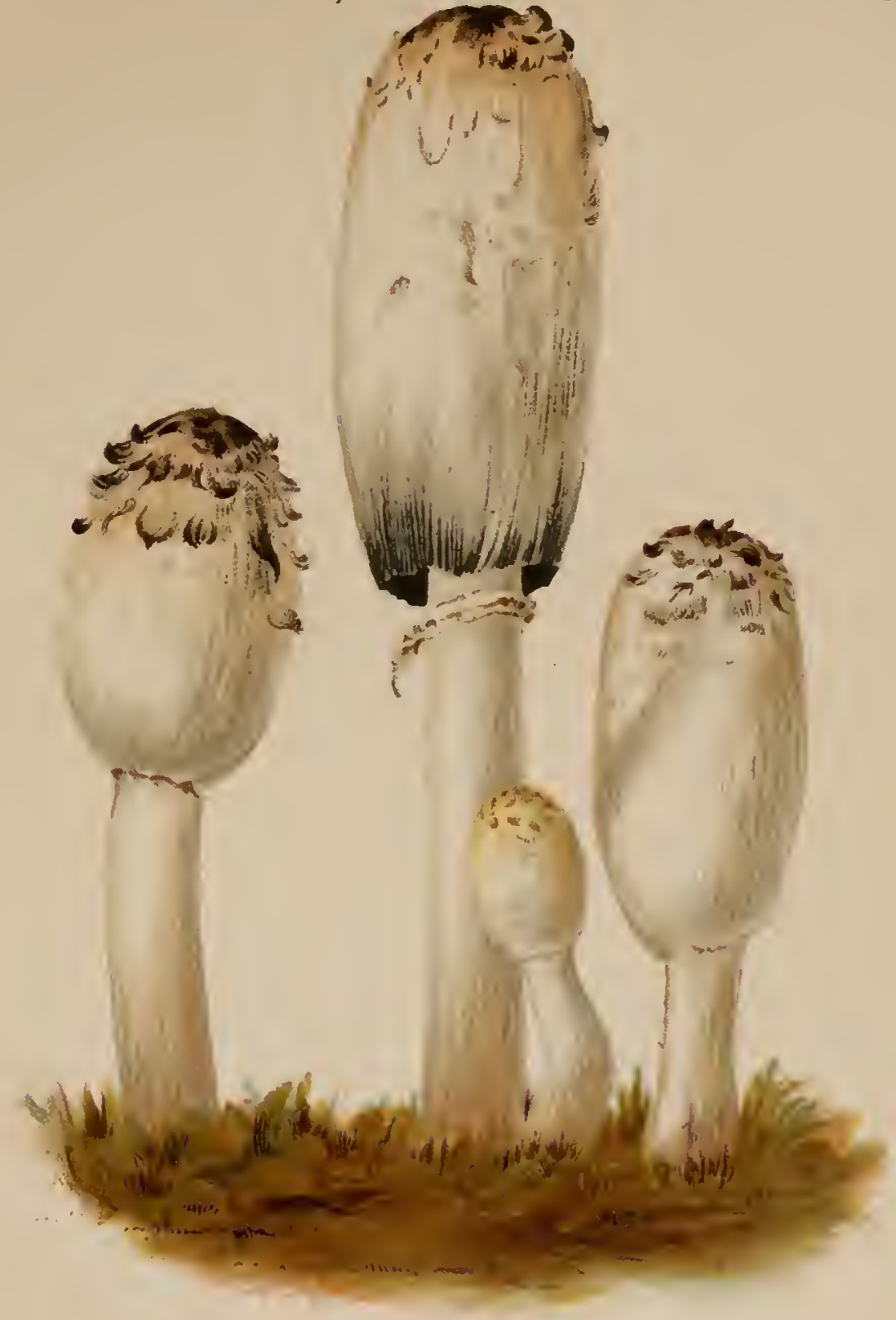

DESCRIPTION. PILkUs. At first oval and hard; margin then separating from the stem; then equally cylindrical, margin turning black; finally expanded, and decaying by dissolution into inky fluid. Color of pileus variable from brown to pure white, al ways woolly, shaggy, the cuticle coming off in layers like the scales of a fish.

Gicls. At first white, crowded; possibly pink, then dark purple, or black, and moist.

Sтемr. Thick at base, equal above ground, hollow, appearing like macaroni cooked.

Volva. None, but ring present, and movable iu the full-grown specimeu.

Spores. Black. Suell strong, especially at centre of pileus.

TAste. Pleasant raw, but should not be eaten after it is inoist and black.

Grows in rich lawns, roadsides, or uewly filled city grouuds, in groups or solitary.

TO COOK. For about twenty mushrooms, put into a saucepan one gill of milk or cream, add salt and pepper to the taste, with a piece of butter the size of the larger specimens above; wlien it boils, put in the stems and small hard mushrooms; after ten minutes' boiling add the larger specimens; keep the dish covered and boiling for ten miuutes longer, then pour the stew over dry toast, and serve.

TO SERVE WITH MEAT. Chop the mushrooms fine, let them simmer ten minutes in one half gill of water, with butter, salt and pepper as for oyster sauce; thicken with flour or ground rice; pour over the meat and cover quickly.

N. B. But very little fluid is needed iu cooking this mushroom, as it yields a rich jnice of its owu. It should al ways be cleaned before cooking, by scraping it smooth and until it is perfectly white. 



\section{MARASMIUS OREADES, OR FAIRY-RING CHAMPIGNON.}

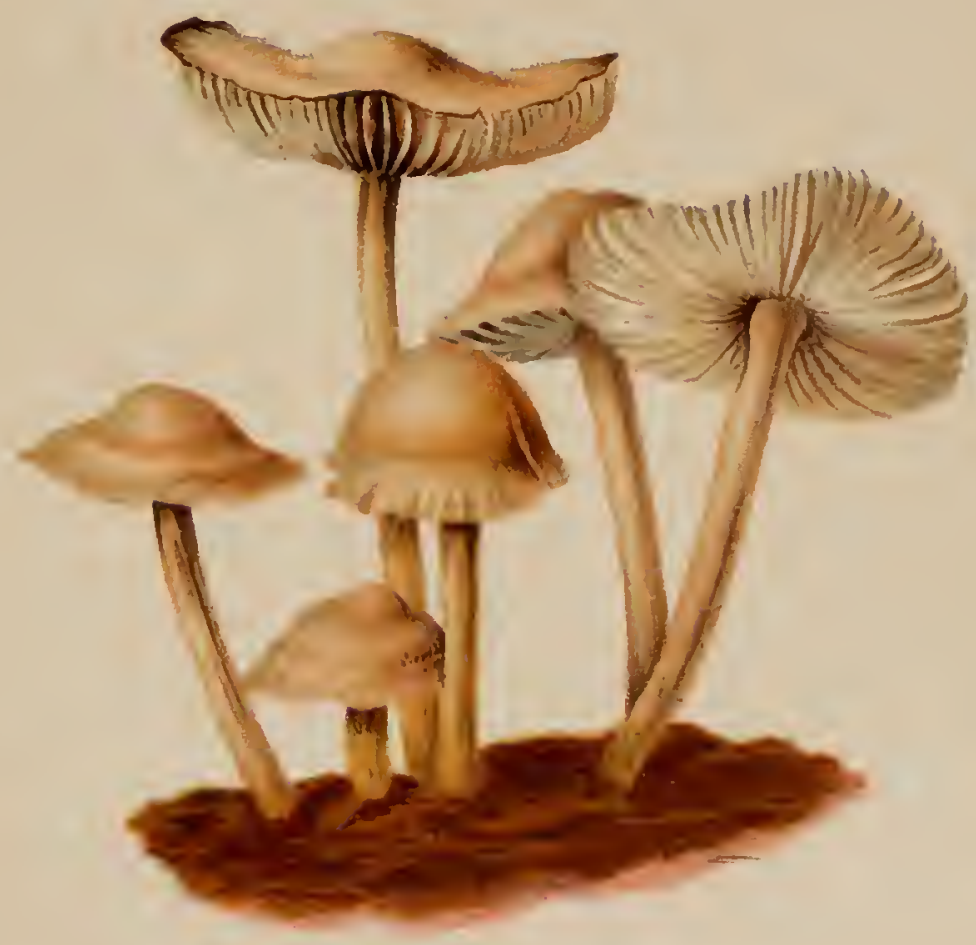

DESCRIPTICN. PILeUs. Leathery, tough, and of an equal cream color, pliahle when moist; shrirelling, wrinkled, eren hrittle when dry, changing from the former to the latter with a dew or rain followed hy a bot sun, and also vice versa. Cnticle not separahle.

Gills. Broad, wide apart, of the same color as pilcus, or a little paler.

STE3. Solid, of eqnal circumference; tough, not breaking easily if bent or twisted.

VoLva and ring, none.

SPORES white.

TASTE and SMELL musky, rather strong, bnt nutty and agreeahle.

Grows in rings or groups in rich lawus or roadsides.

TO coOK. For serving with meat or fish, cut the tops clear from the stems just below the gills. To a pint of mushrooms, if moist, add about a gill of water, pepper and salt to the taste, and a piece of butter half the size of an egg. Simmer togethor over the fire ten or fifteen minutes, thicken with flour or ground rice, and pour over the cooked meat or fisl.

TO BROIL. Place the tops like oysters on a tine wire gridicon; as soon as they are hot, hutter theu lightly, aud salt and pepper to the taste. Put them hack over the coals, aud when they are heated through they are cooked. Butter them, if required, and place in a lot dish.

N. B. Wheu the mushrooms are dried, swell them in water hefore cooking. 



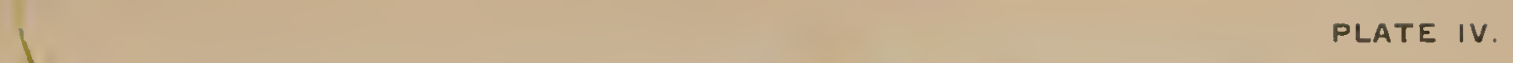

\section{AGARICUS CRETACEUS, OR CHALK MUSHROOM.}

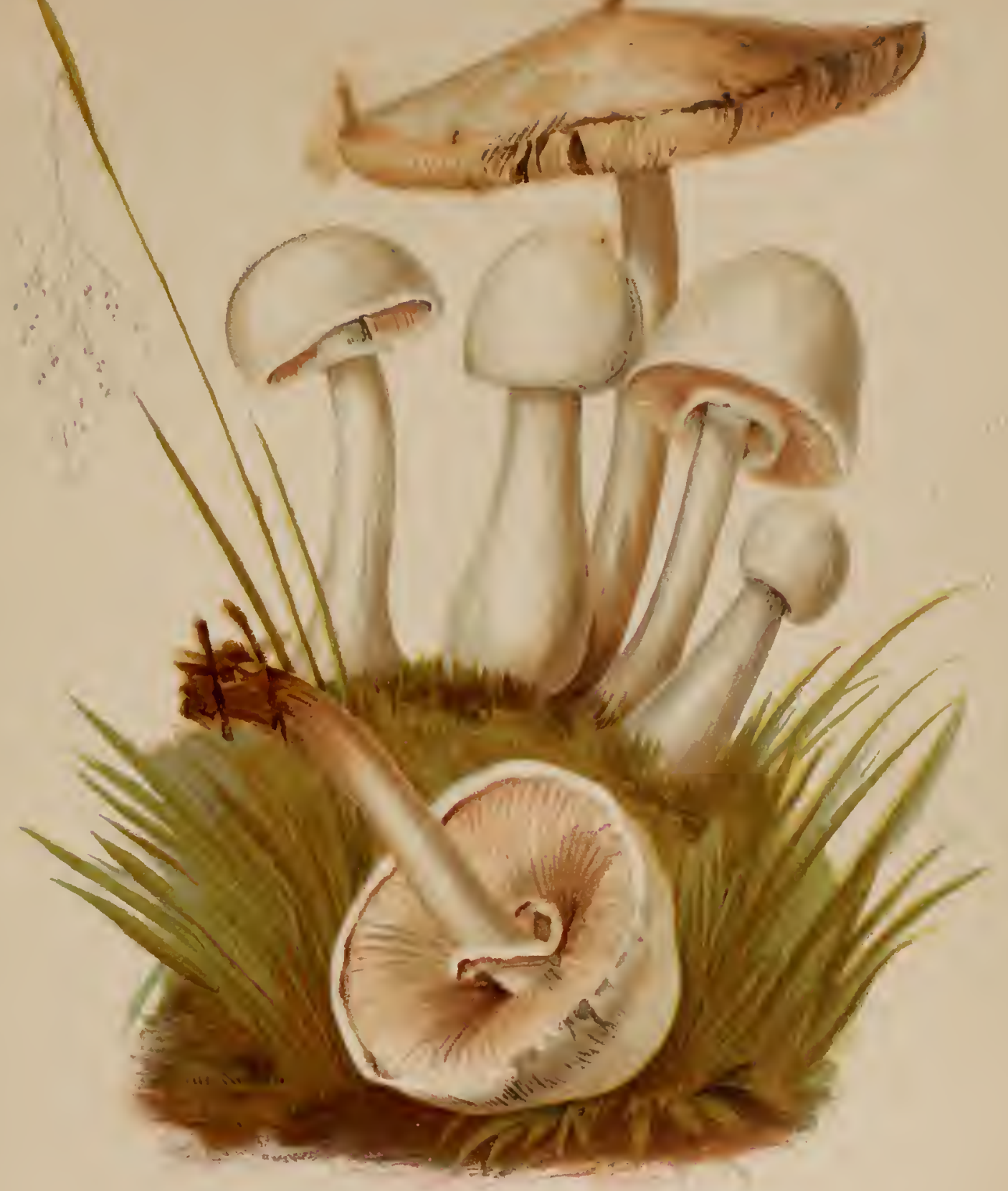

DESCRIPTION. PILEUs. Pure white, dry at first, nearly globular, then hell-shaped, finally expanded and becoming darker, even smoky in color. In early growth very brittle, cuticle always peeling easily.

Gincs. At first pure white, then pinkish, finally rusty; withered in color and texture; always turuing pink or dark if exposed to dry heat.

STEM. Hollow, bulbous at base in small specimens, then elongated and equal; leaves the socket easily, without hreaking into the gills.

Vouva. None; veil distinct and entire, enclosing the gills at first, then ruptured, forming tlie ring.

SPonks. Pale pink or rosy. TASTE, mild, agreeable, but insipin. ODor, uone. Grows in lawns and richly cultivated grass plots; rarely or never in forests.

TO COOK. This mushroom, while sweet and of firm body, has little or no flavor of its own. It inay, therefore, be best to stew it is directed under Plate I., with milk, or under Plate III., with water; in eitler case mixiug some proportion of either or all of the three preceding kinds. In such case, it will completely absorb their flavor. For those who like spices it is very nice cooked as number three for meat or fish, adding to that receipt chopped parslcy, an onion, or a clove of garlic, chopped fine, with a tablespoonful of Worcestershire sauce. If served with any meat making an abundaut gravy, cook as directed under the plate of Edible Russulas. 



\section{AGARICUS PROCERUS, OR PARASOL MUSHROOM.}

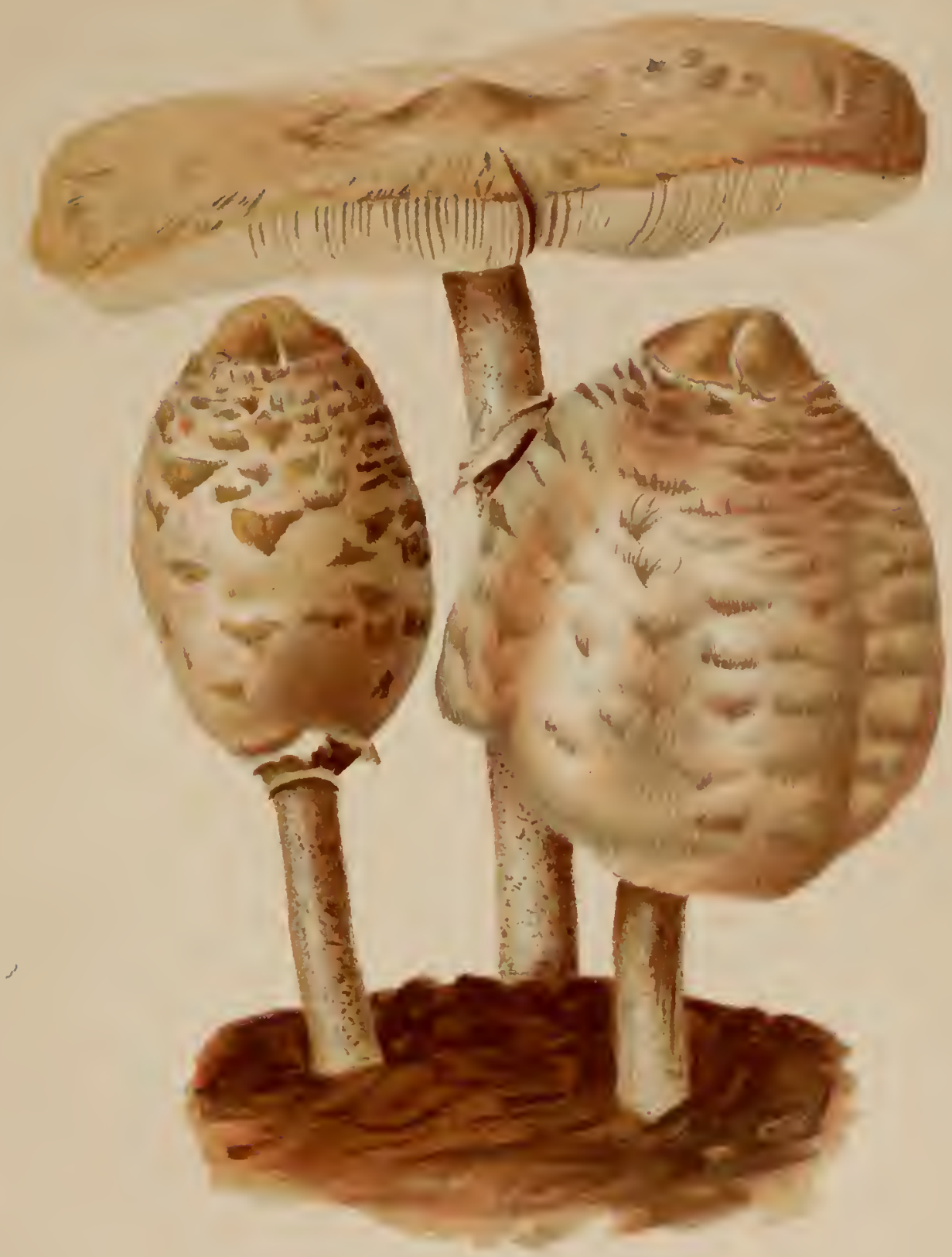

DESCRIPTION. PILEUS. Brown from first to last; thick skinned, very scaly and shaggy; at first egg-shaped, then swollen, finally expanded, a little point in the centre becoming prominent; always pliable and leathery.

Gruss, Pure white.

Sтем. Fibrous, hollow, equal in size, freckled, deeply suuk into the cap, from which it withdraws free from the gills, leaving a deep socket.

Volva. None; veil ragged, ring well defined and movable.

Spores. White. Taste sweetish, not marked; onok slight.

Grows in open fields and lawns or margins of forests.

TO COOK. Stew in milk or cream as directed under Plate II., except that this mushroom is dry and firm. and more liquid may be used, for it will make little or no gravy of its own. It is not of suitable character to be stewed in water, but is very good broiled, requiring the liberal use of butter, or placed under meat as directed with tho edible Russulas. 



\section{EDIBLE RUSSULAS.}

I, 2. Russula heterophylla.
3. Russula virescens.

4. Russula lepida.
5. Russula alutacea.

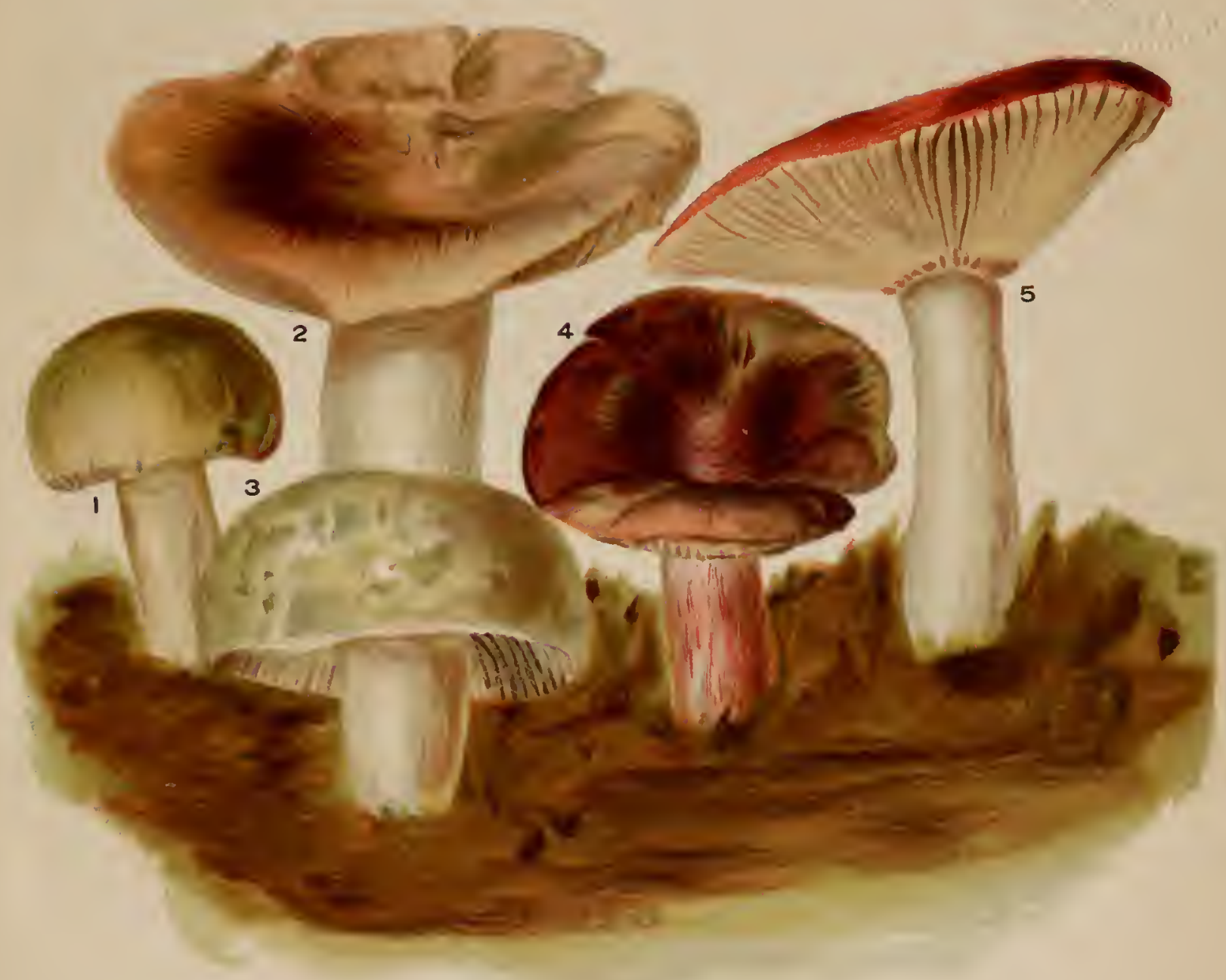

DESCRIPTION. P1LEUs. Many cotored; white, drab, green, purple or bright red; cuticle very thin, preling from the edge, adherent toward the centre; bell-shaped, at first compressing the gills, then expanded, until finally the centre of the cap becomes depressed or concave.

Gills. Generally puro white, sometimes creamy or buff; nearly or quite equal in length, rigid, brittle, breaking into unequal segments if pressed.

STEM. Stout, solid or stnffed; in substance the same as the Hesh of the cap, often tapering quite abruptly to a point at the base.

VoLvA, ring, and veil all entirely absent at every age of the plant.

SPOREs. White. TASTE, excellent raw, like uuts; odor none.

Grows in woods, woody paths or clearings; often found gnawed by squirrels or other animals.

TO COOK. Remove the skin as far as it peels easily, and wash the centre of the cap clean; then place on a gridiron and let them heat through; butter plentifully, and salt and pepper to the taste, then place them in a hot dish in the oven, and after broiling a beefsteak or chicken put it thereon that the gravy may run out and be alosorbed by the mushrooms.

N. B. The noxious members of this family resemble the esculent so closoly that, to the amateur, tasting each one as gathered is the only guide; the hurtful ones being always hot and acrid. Equal gills, extreme brittleness, and dry, firm texture are characteristic of the whole Russula family. 

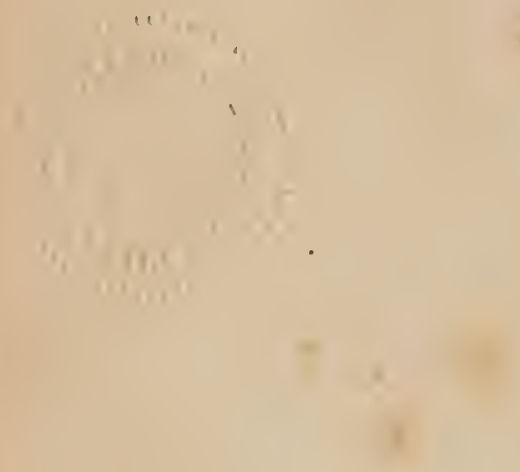

1.

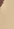

\section{.}

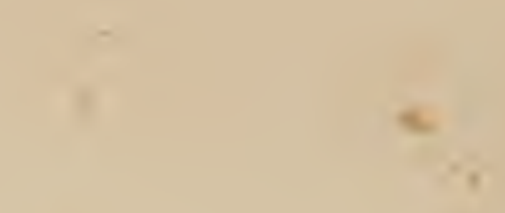

.

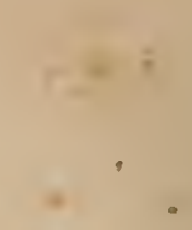

. 



\section{LYCOPERDACEÆ, OR PUFF-BALLS.}

I. Lycoperdon giganteum. Giant Puff-Ball.

2. Lycoperdon saccatum. Little Puff-Ball. 3. Lycoperdon gemmatum. Pear-shaped Puff-Ball.

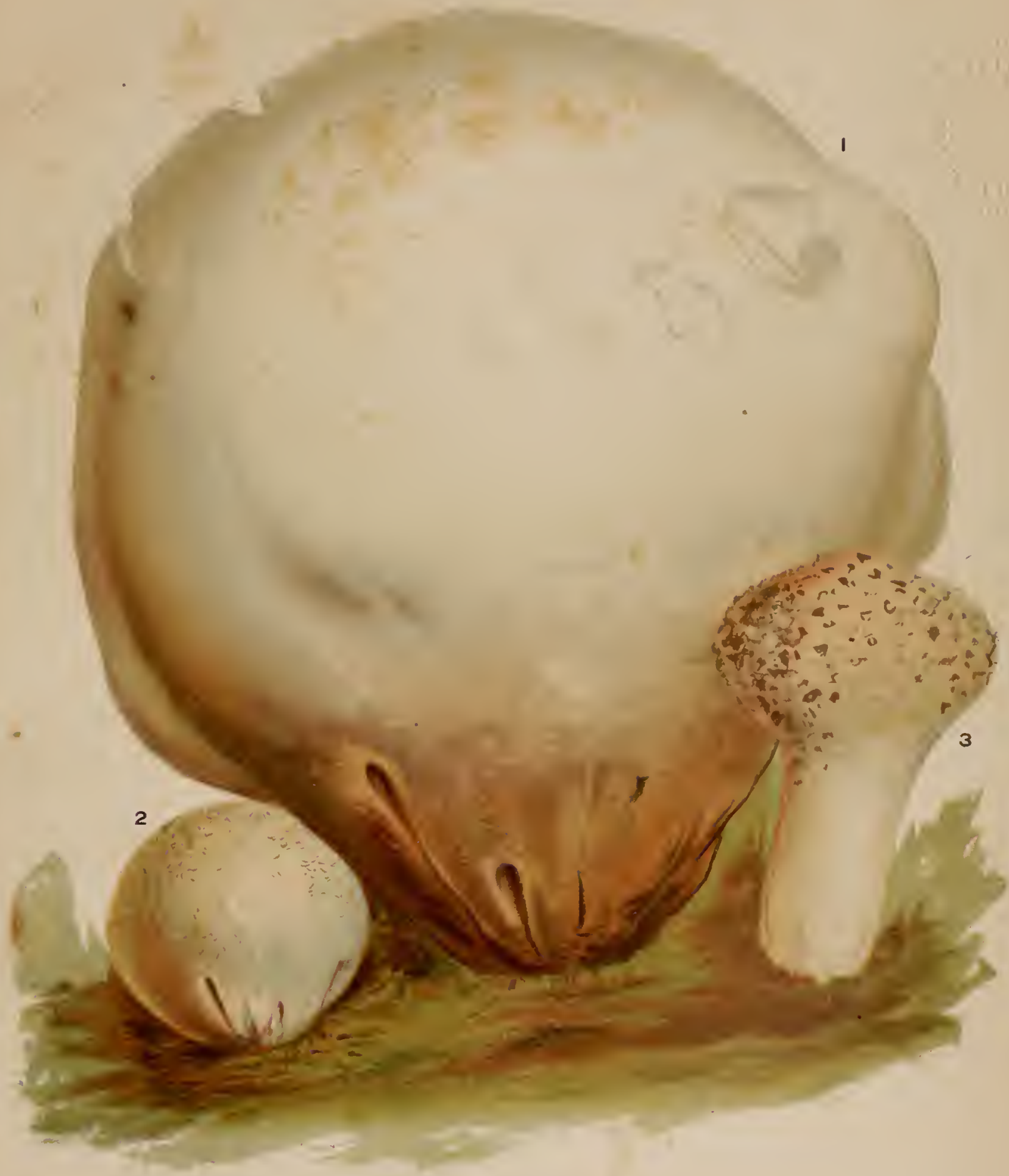

There are many varieties corresponding in most points with some one of the three above niunerl, some growing on stumps, but most of them appeariug on sandy soils after lieavy rains. None are poisonous.

TO COOK. Make a batter, properly seasoned as for frying egg-plant, or beat up egrs for the same purpose; cut the puff-balls into slices half an inch tlick, and fry in boiling fat or ull a buttered gridelle. Puff-balls are also very good stewed with the Coprinus, or with the ordinary musliroom, as their porous substance absorbs the stronger Havor. 



\section{AGARICUS (AMANITA) VERNUS, OR POISONOUS WHITE MUSHROOM.}

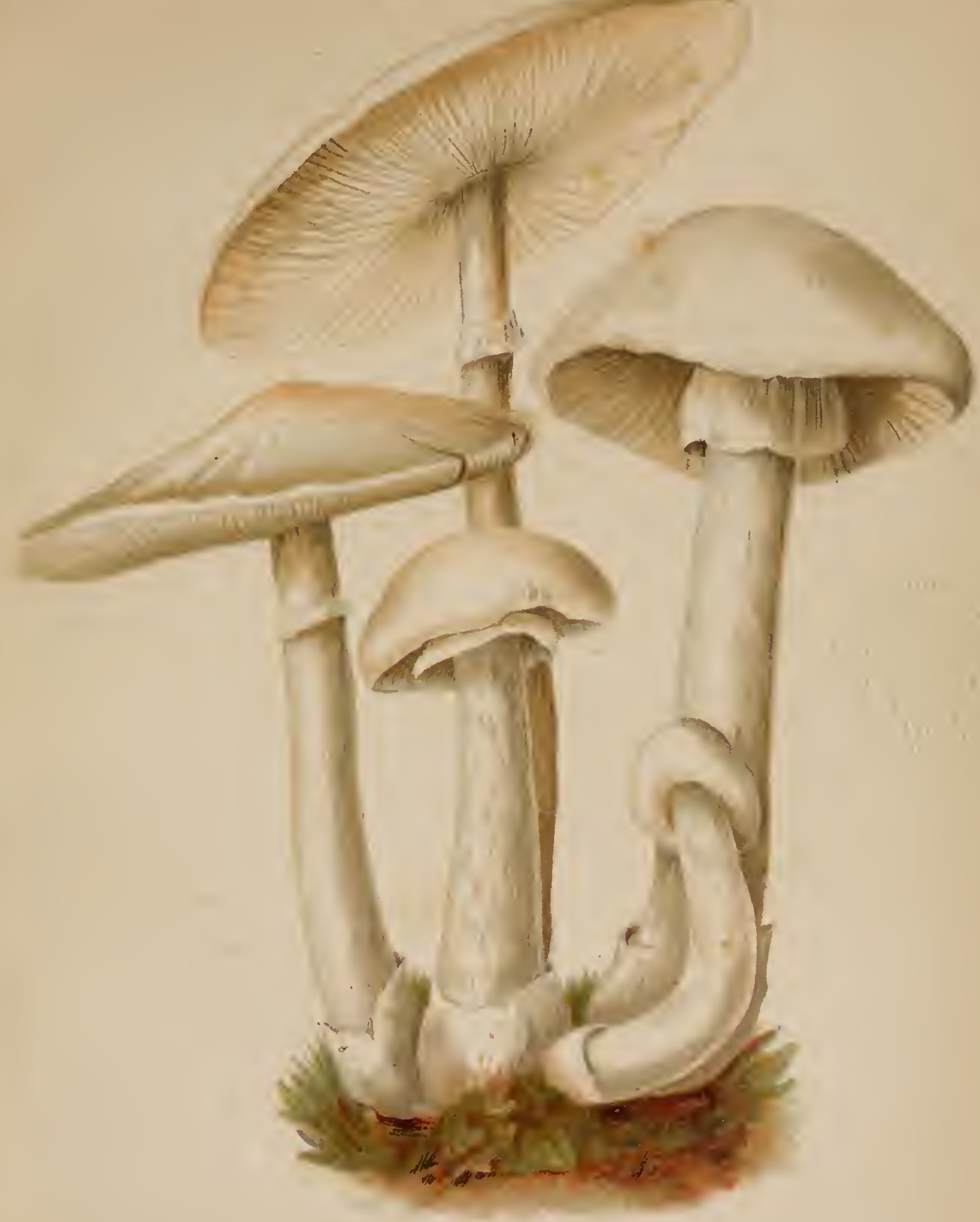

DESCRIPTION. PILeus. At first ovate or bubous, enclosed in the volva, then expanded, always pure white, usually clammy or viscid to the touch; euticle tlin, separable.

Gilcs, Pure white, unequal, free from the stem.

Sтем. Long, rough or woolly, stuffed or a little hollow toward the cap.

Vouvs. Always present. Ring marked at medium growth; often absent at maturity of the plant; aud the same is true of the warts or scurt on the cap.

N. B. This mushroom to many persons lias no disagreeable taste or smell. It grows in and on the borders of woods, and when half open may easily be taken for those in Plates I. or IV., if attention is not paid to the volva. It is deally poison. 



\section{POISONOUS MUSHROOMS OF THE GENUS AMANITA.}

\section{Agaricus (Amanita) muscarius. 2, 3. Agaricus (Amanita) phalloides. 4. Agaricus (Amanita) mappa.}

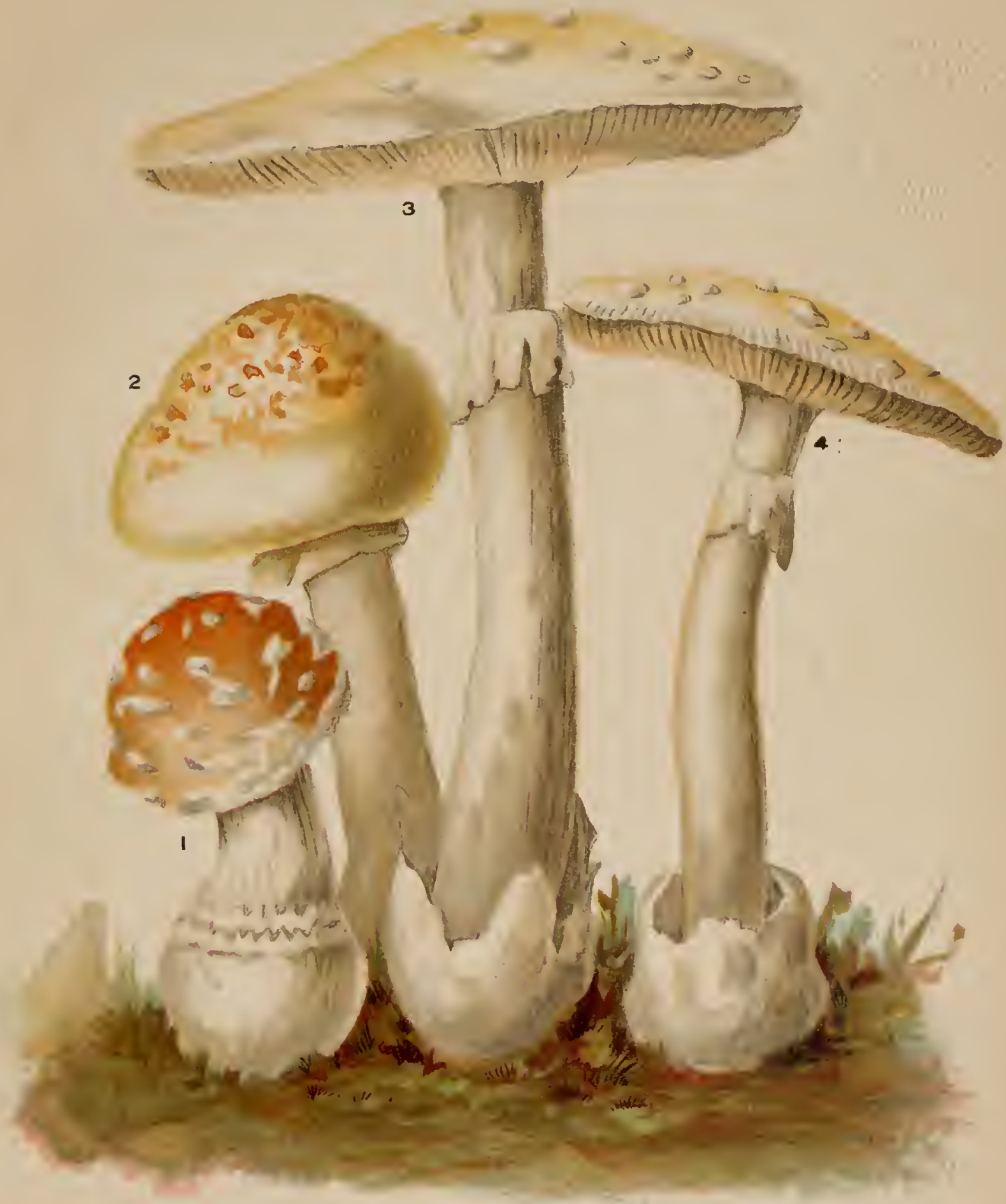

GENERAL DESCRIPTION OF ABOVE. Plant when just below tho soil enclosed in a volva or wrapler, which as it matures remains (1) at the base continuing to sheathe the stem; (2) in the collar or ring; (3) on tlee pileus in the form of easily separable scales or warts. Generally free from disagreeable taste or smell, except at decay, when the variety illustrated by figures No. 2 and No. 3 is putrid and nanseous. Gills pure white at every stage of growtl. Pileus vory variable in color, from pure white to bright orange or red. All con tain a deadly poison. 



\section{POISONOUS OR SUSPICIOUS BOLETI.}

I. Boletus felleus, Bitter Boletus. 2. Boletus alveolatus, Crimson Boletus. 3, 4. Boletus luridus, Lurid Boletus.

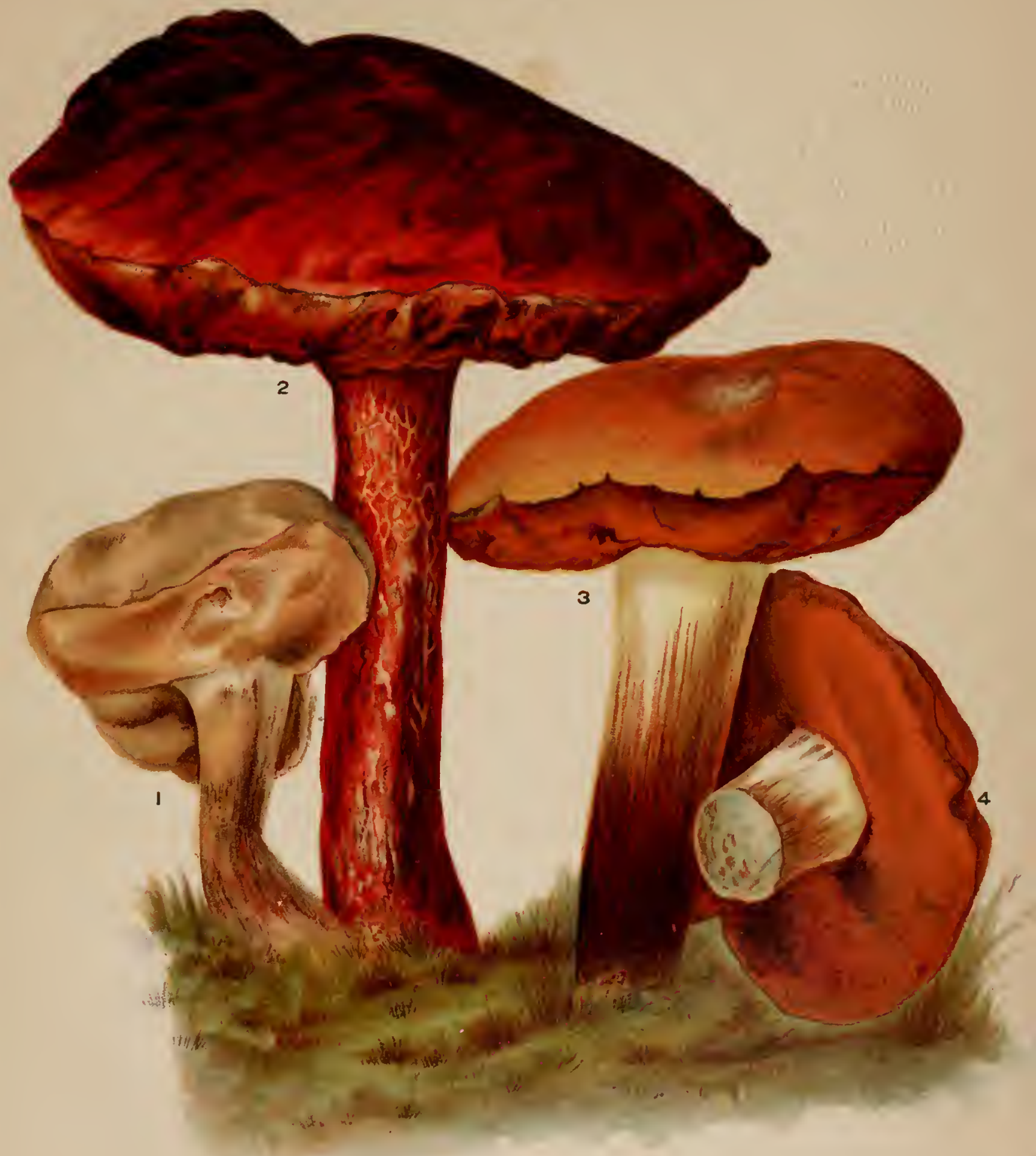

Froure 1 above is very much like Figures 2 and 3, Plate VII., of Edible Mushrooms, from which it is easily distinguisled by its bitter taste and rosy tubes.

Froure 2 is a distinctively American species, and the authority for suspecting it is found in the fact that all Boleti which have red or red-mouthed tubes liave been considered poisonous. Although valuable for an illustration of the lurid Boleti, this variety is probibly edible.

Fraure 3 is easily confounder with Figures 4 and 5, Plate VII, cf Edible Mushrooms, if attention is not paid to the color of the tubes. 



\section{POISONOUS OR FALSE CHAMPIGNONS.}

\section{1, 2. Agaricus (Naucoria) semi-orbicularis. 3,4. Agaricus (Stropharia) semi-globatus. \\ 5, 6. Agaricus (Naucoria) pediades.}

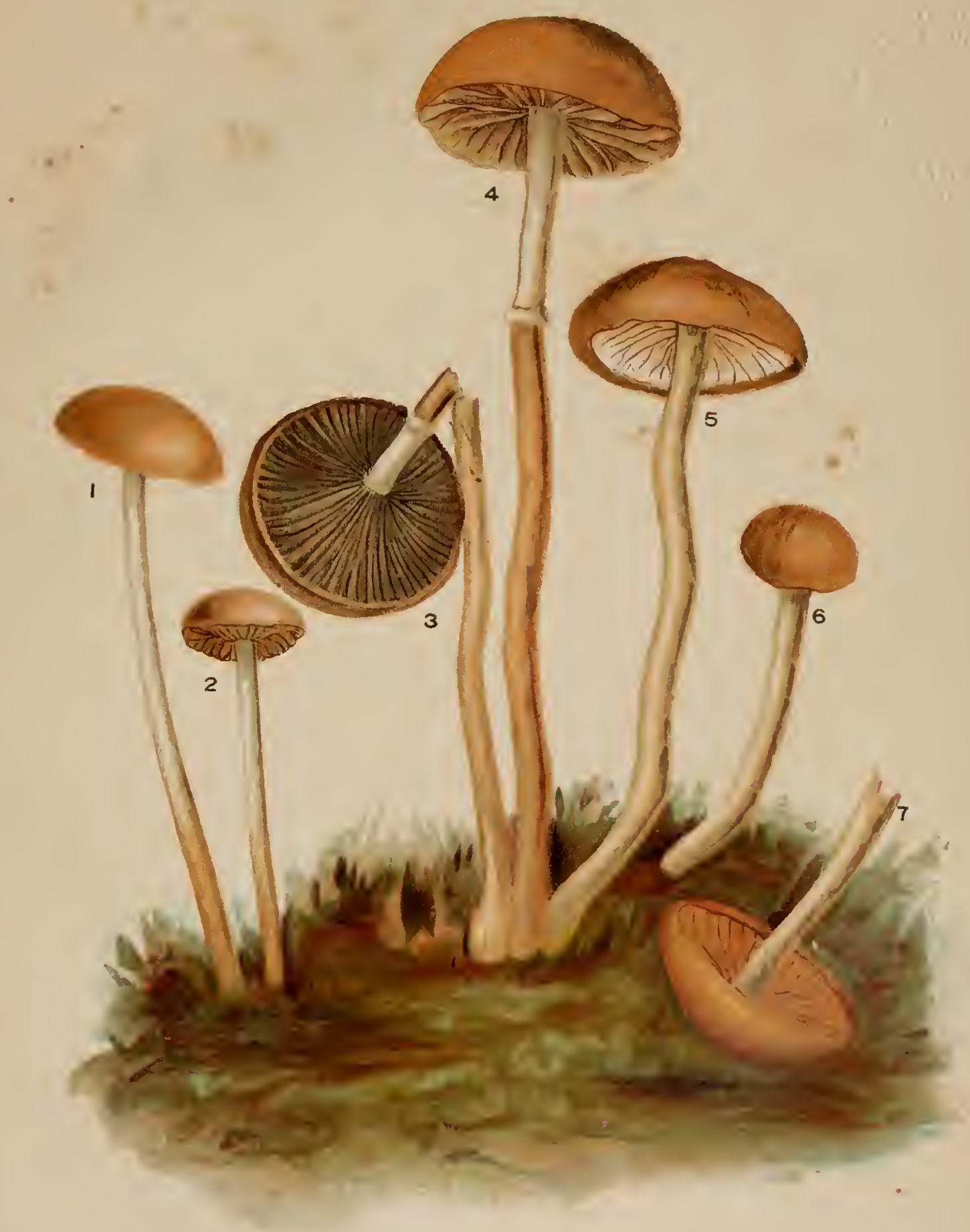

Figure 1 and Figure 2 above are of a small mushroom which grows in lawns and pastures, and is very easily mistaken for those on Plate III. of Edible Mushrooms; but, first, they have no point, but are strictly orlicular; second, the gills are always discolored in age or decay as in Figure 7 above; third, the texture is soft, and the mushroon does not dry hard by the sun and re-expand with moisture as a Marasmius.

Fioures 3 and 4 as also 5 and 6 illustrate species oftenest found in or on manure, and the above distinctions are equally true of these two varieties. The above are not known to be assurediy poisonous, but have none of the esculent qualities of the fairy-ring champignon. There are also other suall fungi of soft texture and doubtful quality closely resembling these which grow in lawns and pastures, and the object of this plate is to teach the amateur to avoid all such. The suspicious varieties of Marasmius do not grow with the edible species, but in woods. 



